\title{
EL TRATAMIENTO ÉTICO DEL TRAUMA EN LAS FICCIONES TESTIMONIALES RECIENTES*
}

\author{
Sandra Beatriz Navarrete Barría**
}

\section{Resumen}

En este artículo revisaremos un corpus de novelas argentinas y chilenas recientes que, de acuerdo a nuestra hipótesis, presentan una estética narrativa particular que interpela al lector gracias al tratamiento ético del trauma que desarrollan. Estas novelas trabajan la memoria social de las dictaduras, destacando el rol ético del oyente para la elaboración del testimonio. Específicamente, se potencia el 'impacto ilocucionario' en la narración del trauma para generar el 'juicio reflexionante' en los lectores.

Palabras clave: Testimonio, ficciones narrativas, daño moral, impacto ilocucionario, juicio reflexionante.

\section{ETHICAL TRATMENT OF TRAUMA IN RECENT TESTIMONIAL FICTIONS}

\begin{abstract}
In this article we are going to revise a group of recents novels from Argentina and Chile, who presents a particular narrative aesthetic. According with our hipothesis, this aesthetic interpellates the reader because of an specific ethical treatment of the trauma which the narration developes. These novels work on the dictatorship's social memory, underlining the moral rol of the listener for the testimony elaboration. Specifically there is a stimulation on the 'ilocutionary impact' in the trauma's narration to generate the 'reflectirend judgment' in the readers.
\end{abstract}

Keywords: Testimony, narrative fictions, moral damage, Iillocutionary impact, reflectirend judgment.

Recibido: 16-06-2015

Aceptado: 21-10-2015

* Este artículo se enmarca dentro del Proyecto Fondecyt Posdoctoral $N^{\circ}$ 3140072, titulado "Desplazamientos e interpelaciones de la memoria traumática reciente: diálogos entre el testigo y el oyente" (2014-2016), del cual soy investigadora responsable

** Chilena, Doctora en Literatura de la Pontificia Universidad Católica de Valparaíso. Investigadora Fondecyt, Académica IDEA, Universidad de Santiago de Chile, Santiago, Chile. Sandra.navarrete.b@ gmail.com 


\section{La pregunta por la ética en la memoria}

Abordar el problema de la memoria desde la arista ética parece bastante pertinente si apreciamos las vejaciones a los derechos humanos en dictadura como un asunto social aún vigente y consideramos la literatura como un elemento del discurso social que opera sobre otras textualidades de la memoria². Pero, específicamente, ¿a qué nos referimos con la dimensión ética de la memoria? Para Héctor Schmucler (2000), la memoria es un hecho moral en la medida que se debe a una selección de recuerdos colectivos no azarosos. "La memoria ha elegido aquellos recuerdos que la constituyen y esa elección -aunque nuestra conciencia al respecto sea precaria- se asienta en principios derivados de alguna construcción ética" (5).

En opinión de Hugo Vezzetti (1994), la memoria argentina fundó una tradición ética a partir de la investigación de la CONADEP y el juicio a los dictadores, que se sintetiza en la ecuación: memoria + verdad + justicia= 'nunca más' (Vezzetti 2). En el caso de Chile, también se llevaron a cabo medidas de reparación simbólica, como el Informe Rettig, la Mesa de Diálogo sobre Derechos Humanos y La Comisión Valech ${ }^{3}$. Estos hechos apelaron a los valores de verdad y justicia para la sanación del país durante la transición. Sin embargo, al mismo tiempo, instauran el concepto de 'justicia en la medida de lo posible ${ }^{4} \mathrm{o}$, en términos de Nelly Richard $^{5}$, la 'democracia de los acuerdos', que hizo del consenso su garantía normativa.

En suma, cuando Schmucler (2000) se refiere a la memoria como un hecho moral, coloca el acento, más que en los actos públicos, en la norma

2 La perspectiva metodológica sociocrítica es la que orienta nuestro estudio, específicamente la que propone Marc Angenot (1991, 1998, 2015). De este modo, entenderemos la literatura como un discurso social que trabaja interdiscursiva e intertextualmente sobre los demás elementos que constituyen el discurso social. Consideramos que los distintos ejercicios de la memoria posteriores a las dictaduras en Argentina y en Chile han construido un núcleo temático, alrededor del cual se gestan distintas textualidades que van generando debates y disputas de sentido en torno a lo que se debe recordar y lo que no.

3 Además se puede agregar el arresto al jefe de la ex- DINA, Manuel Contreras, en 1995.

4 Waleska Pino Ojeda explica este concepto desde sus dos posibles acepciones: actuar dentro de lo posible representa un acto de responsabilidad política que protege los intereses de paz social, sin por ello sacrificar el develamiento de la verdad [...] el conflicto no radica del todo en la lógica del mayoritismo, sino sobre todo en lo que 'lo posible' fue establecido de antemano, esto es, como un hecho predeterminado en donde se optó por trabajar con limitaciones antes de estudiar hasta qué punto éstas realmente eran inamovibles. (Pino-Ojeda 84)

5 "Tribunales, comisiones y monumentos a los derechos humanos citan regularmente a la memoria (hacen mención de ella y notifican el pasado), pero dejando fuera de sus hablas diligentes toda la materia herida del recuerdo [...] cuyo dolor no se apacigua con la fórmula meramente cumplidora del trámite judicial y de la placa institucional" (Richard 31). 
moral que opera tras ellos y en cómo dichas selecciones del recuerdo social afectan, recaen e interpelan a la ciudadanía en general. De este modo, observamos cómo en ambos países -con sus matices particularesse han conformado distintos núcleos o hitos de la memoria social ${ }^{6}$ que van hilvanando el debate público en torno a determinadas preguntas y temas que van adquiriendo preponderancia en momentos determinados.

Ahora bien, cabe preguntarse si estos núcleos de la memoria interpelan efectivamente a la audiencia en su mayoría, permitiendo un ejercicio de reflexión moral abarcador en pos de la comprensión del pasado. Para Waleska Pino-Ojeda (2011), este ejercicio debe desencadenar en un compromiso ético, en donde la instancia de recepción juega un rol fundamental. La transmisión de estas experiencias abyectas debe "involucrar a la comunidad amplia en este proceso, y si no es posible hacerlo apelando a una empatía solidaria, al menos es dable esperar que haya escuchas atentos, una audiencia afable" (269). Nos preguntamos entonces: ¿Qué modos de transmisión pueden propiciar estas audiencias afables? ¿Qué mecanismos comunicativos generan escuchas atentas en la ciudadanía?

En opinión de María Pía Lara (2009), es gracias a la forma en que muchas historias sobre el pasado circulan en las sociedades que éstas mismas han podido tomar consciencia sobre su pasado. Es decir, no es solamente el conjunto de actos públicos o trabajos de la memoria -museos, comisiones por la verdad, juicios- los que van construyendo una reflexión moral en la ciudadanía, sino que también, y sobre todo, las narraciones sobre el pasado, ya que ellas han incidido en las conciencias colectivas sobre el trauma, como fenómeno histórico compartido. Para esta filósofa, las narraciones sobre el mal y el horror reciente:

poseen un potencial de revelación acerca de las oscuras dimensiones de la crueldad humana. Las descripciones que provienen de las historias particulares nos provocan un shock, ya que permanecen en nuestra conciencia de

6 Manuel Garretón (2003) explica que la memoria colectiva “supone un núcleo duro básico compartido, aunque cada uno se 'descuelgue' y se incorpore de modo diferente, por su historia propia, por sus imaginarios, por sus intereses, a ese núcleo duro" (224). En Chile, específicamente, el autor estipula tres hitos fundantes: 1. La crisis del proyecto nacional-popular de la Unidad Popular, 2. El golpe militar y la dictadura y 3 . El Plebiscito y la redemocratización política (simbolizados los dos últimos en el 11 de septiembre y el cinco de octubre, respectivamente). 
muchas maneras [...] Esto sucede porque tales narrativas develan algo que éramos incapaces de ver antes de haberlas contemplado como si fueran la vida misma. Estas expresiones dramáticas son reveladoras porque nos posibilitan ejercer nuestro juicio (Lara 16).

Tomaremos esta hipótesis como marco interpretativo para abordar las ficciones narrativas del presente estudio y entenderlas como textos que poseen un potencial develador del mal, gracias al filtro moral y estético que desarrollan. Nos interesa delimitar la construcción del 'efecto ilocucionario', es decir, aquel efecto que se produce cuando la dimensión de la realidad que el autor describe se materializa frente a los ojos del espectador y se genera una interacción comunicativa entre el ego (autor) y el alter (los públicos), promoviendo, en definitiva, el juicio moral en los lectores (Lara, 2009). A continuación, analizaremos un breve corpus de novelas argentinas y chilenas, para observar cómo estas obras configuran nuevas significaciones éticas sobre el trauma al interpelar directamente al oyente colectivo.

\section{La vida doble de Arturo Fontaine o la textualidad de la traición}

La vida doble relata el pasado traumático de una mujer militante de izquierda que traiciona. La voz narrativa está a cargo de Irene, la protagonista, quien le cuenta su biografía a un entrevistador (un escritor chileno). Esta ficción testimonial ${ }^{7}$ trabaja la dimensión ética del trauma a través de dos operaciones principales: por un lado, ensaya una nueva perspectiva sobre el 'daño moral' de las víctimas de represión, situando en el centro a un personaje que coopera con sus victimarios y, por otro lado, instala en primer plano la situación comunicativa que propicia el testimonio, destacando el papel ético que juega el receptor.

La propuesta de Lara para comprender el rol social de las narrativas del mal pone su atención en la descripción del daño realizado por el perpetrador. Si estos actos son descritos 'poderosamente', el lector adquirirá la noción de lo que realmente está en juego -moralmente

7 Denominaremos ficción testimonial a aquellas obras que trabajan discursivamente sobre una serie de testimonios reales, elaborando una narración ficcional que le debe mucho a la realidad. En este caso, sabemos que Arturo Fontaine se basó en una serie de testimonios para crear su novela, los que incluso aparecen citados bajo el título "Fuentes", al final de la novela. 
hablando- (Lara, 2009). En La vida doble, las descripciones de la tortura son poderosas, destacándose la del momento de delación, cuando la amenazan con su hija:

Primero fue una foto y después un video, un par de minutos de video proyectado en una pequeña cámara de televisión que alguno de ellos enchufó y puso en el suelo: ella, ella saliendo del colegio con su faldita azul. Venía conversando con una amiga y la sentí reírse. Eso fue. Necesito que ella pueda seguir riendo, me dije. Entonces me rendí. Entonces me convertí en una de ellos. (Fontaine 143)

Otro modo a través del cual observamos el daño moral es la relación con su verdugo, donde se aprecian las formas en que éste es valorado como su salvador o creador. "Debo nacer de nuevo para el Flaco, para el Gato, soy una mujer nueva, 'La Cubanita', Consuelo Frías Zaldívar, natural de Matanzas, la que está interrogando al Chico Escobar y a Briceño" (Fontaine 155).

A pesar de que la narración de la tortura y de la relación con su victimario nos permiten comprender el otro lado de Irene, son mucho más numerosas las descripciones y reflexiones sobre la amoralidad de este personaje, anteponiendo una suerte de maldad inmanente en su actuar. En este sentido, la perspectiva que prevalece en la novela es la del mal representado como algo abstracto y extraordinario, lo cual, por un lado, otorga características demasiado particularizantes al personaje y, por otro, resta responsabilidad al contexto de dictadura que propició prácticas sistemáticas de violación a los derechos humanos. En suma, creemos que Fontaine, al presentarnos una subjetividad tan avasalladora como la de Irene, resuelve el dilema ético de la traición, ubicando a su protagonista más allá de la dimensión moral, construyéndola como un personaje de excepción -como una especie de antónimo de lo que Arendt denominó la banalidad del mal- ${ }^{8}$.

8 Coincidimos con Jaume Peris Blane (2013) cuando expresa que la novela de Fontaine "incide en una representación de la represión que, aunque sea novedosa en algunos aspectos, la conceptualiza como un estadio irracional y, por tanto, incomprensible fuera de los paradigmas explicativos del mal, el horror y la abyección" (59). En función de esto, explica Peris Blane, La vida doble propondría una visión bastante similar a la que difunden las políticas institucionales de la memoria en Chile, caracterizadas por aislar al neoliberalismo de la supuesta violencia irracional y de excepción que aconteció en dictadura. 
El segundo mecanismo de lo ético es la configuración de la situación comunicativa que encuadra el relato testimonial. Fontaine focaliza en primer plano la interacción entre testigo (Irene) y oyente (Entrevistador); sin embargo, como el oyente no emite comentarios ni conocemos su voz narrativa, la textualidad de la novela potencia a los mismos lectores como receptores extradiegéticos de Irene. En otras palabras, la mitad de conversación que nos entrega la novela, las preguntas sin respuesta y los reclamos sin defensa, van acumulando una necesidad comunicativa que al no ser resuelta en el texto, se dispara hacia el receptor extratextual. Esto genera un 'impacto ilocucionario', una nueva manera de subrayar el daño moral gestado en los centros de tortura, no ya desde la voz inocente de la víctima, si no que desde una víctima que se ha transformado en victimaria.

Lo interesante es que la novela escenifica el contexto de producción del testimonio, que es al mismo tiempo contexto de recepción, y así el relato es frecuentemente interrumpido por preguntas y respuestas que van instalando un 'efecto ilocucionario's, sin encerrarse en un yo autosuficiente. Preguntas del tipo: “ite lo dije, no es cierto? -del Espartano. No conocí a nadie como él. Me gustaría hacerte un retrato de su alma" (92) o "¿Y qué quieres que te conteste desde la cama en este hogar de Ersta?" (125). Estas preguntas, lejos de ser retóricas, van configurando un espacio de interrelación que imita la oralidad. Como explica Susana Kaufman (2014), en los testimonios orales "el narrador y su escucha participan de reflexiones, de la reafirmación de la veracidad del pasado y del trabajo de su asimilación al momento de la vida actual" (Kaufman 112).

La influencia del receptor en el entramado del testimonio oscila entre la preponderancia del oyente en lo relatado: "Me elaboro con palabras para ti, me encumbro sola en mi propio aire, y eso soy, entonces, un flujo de sonido que emana de las cuerdas de mi garganta y pongo a tu alcance, nada más" (Fontaine 161) y la autonomía de la testigo: "¿Podría yo decirte la verdad? Ésa es una pregunta para ti. ¿Me vas a creer o no? A eso sólo lo respondes tú. Lo que yo sí puedo hacer es hablar. Y allá tú si me crees" (11). De este modo, se configura un campo de ambigüedad que va constantemente desestabilizando y actualizando

9 María Pía Lara (2009) explica que cualquier interacción comunicativa entre autor y lector que genere un debate de tipo ético será entendida como una acción ilocucionaria. 
la situación comunicativa. Finalmente, Fontaine consigue una forma expresiva novedosa al instalar la situación enunciativa del testimonio en primer plano, en medio de la alteridad entre testigo y oyente; sin embargo, la excepcionalidad que le atribuye a su protagonista la alejan de la referencialidad de represión y tortura a la que pueda apelar su testimonio, transformando el debate moral en una pregunta metafísica por el mal en los seres humanos.

\section{Dos veces junio de Martín Kohan: La necesidad del juicio ético en el lector}

La narración está a cargo de un conscripto que oficia de chofer para el Dr. Mesiano. Ambos trabajan en un centro de detenciones ambientado en 1978. Todo se inicia con un conflicto que involucra, por un lado, a una mujer que ha sido brutalmente torturada y que acaba de parir, y por otro, a sus captores. El timbre a/moral o 'el relato de lo banal' (Arpes y Gasel, 2011) que alcanza Dos veces junio ha sido ampliamente trabajado en distintos estudios $^{10} \mathrm{y}$ fue reconocido por el mismo Kohan en una entrevista, en donde explica que buscaba un nuevo registro para trabajar el trauma, de modo tal que rehuyera de la focalización victimista, reivindicativa y realista: “En la resolución mía del tipo del narrador, la idea es que fuera un narrador atrozmente amoral. Obviamente, eso admite una lectura moral posterior, pero esa carga yo quería generarla como reacción de lectura, nunca en la escritura" (Kohan citado en Dalmaroni 163).

Dicha reacción de lectura es lo que María Pía Lara (2009) denomina 'juicio reflexionante' y se consigue no solamente al insertar una historia con un fuerte peso ético, sino que también gracias al trabajo de la forma lingüística: en la conjunción constante de ambas dimensiones, se configura la perspectiva develatoria de las narraciones del mal. En este caso, el autor nos presenta un mundo plagado de personajes amorales que se enfrentan al horror que los circunda de manera neutral y pasiva, y así la responsabilidad moral recae directamente en el lector. Como explica Souto (2013): “En la novela, la única desestabilización será la que se plantee el lector, que en ningún caso podrá permanecer pasivo" (45).

10 Ver "Los subalternos en las ficciones de apropiación de menores" de Luz C. Souto (2013); "La escritura literaria del trauma y las deconstrucciones de los mitos históricos en el territorio de la literatura argentina actual" de Marcela Arpes y Alejandro Gasel (2011); "La palabra justa. Literatura política y memoria en Argentina. 1960-2002" de Miguel Dalmaroni (2004); entre otros. 
Para analizar el rasgo interpelativo de Dos veces junio, nos concentraremos en dos momentos. En primer lugar, en la pregunta fundante del relato: “¿A partir de qué edad se puede empesar a torturar a un niño?" (Kohan 11) y, en segundo lugar, en el encuentro entre el protagonista y la mujer torturada. Ambas instancias cumplen una función comunicativa y simbólica: comunicativa en la medida que provocan una reacción en el lector, y simbólica en tanto sus personajes representan los roles sociales que han cumplido, víctimas y oyentes, en la elaboración colectiva del testimonio postgolpe. El tono neutro y accidental en el que se nos filtra la información sobre la posible tortura de un bebé para obtener información de la madre, engrosa y acentúa tanto la dimensión moral como la fuerza comunicativa de la pregunta que nos hacemos como lectores: ¿Cómo es posible que el narrador se moleste con la 's' mal puesta de una palabra y no con el contenido total de la pregunta?

Este mismo horror que atraviesa todo el mundo narrativo, pero que no convoca a ningún personaje, es el que, por un efecto de rebote, se desplaza y apela al lector. Este mecanismo de desplazamiento es el que permite la conjunción entre el asunto ético (apropiación de menores, tortura a las madres embarazadas) y lo estético o eso que Beatriz Sarlo ha denominado 'control artístico'. Nos dice Sarlo (2005) sobre Dos veces junio:

Sin el control artístico, esa pregunta inicial impediría construir cualquier historia, porque la escala del horror la volvería intransitable, obscena. Congelada y al mismo tiempo conservada por la narración "artísticamente controlada", la ficción puede representar aquello sobre lo que no existe ningún testimonio en primera persona: el militar apropiador de chicos, hundido en lo que Arendt llamó la banalidad del mal; y el soldado que lo asiste con disciplina inconmovible, ese sujeto del que tampoco hay rastro testimonial. (164)

El segundo momento clave es cuando el narrador se enfrenta a la solicitud de ayuda y al testimonio de la prisionera. Esta es la única instancia en donde observamos al sumiso conscripto comportarse con soberbia y desprecio:

La voz traspasaba la puerta como si la puerta no existiera.

De este lado de la puerta estaba yo. La voz traspasaba la 
puerta para contarme las cosas que pasaban. Yo le dije: "Callate, hija de puta, callate de una vez". Pero ella siguió, apurada, y no obstante el apuro, se detuvo en detalles. Yo no dejé de decirle: "Te estoy diciendo que te calles, hija de puta, callate de una vez", porque empezó con los detalles y a mí me hartaban los detalles. Pero siguió, y siguió sin ahorrarse los detalles. (Kohan 138)

Esta escena, además de mostrar la necesidad del 'oyente' para la existencia del testimonio, representa la posibilidad de que este mismo oyente se resista o se niegue rotundamente a escuchar lo testificado. Además, permite observar cómo un subordinado inserto en el sistema del horror no es más que "alguien que simplemente encuentra una especie de atajo para no hacerse cargo de lo que tiene delante de los ojos" (Kohan en Aldaño p. 8).

El testimonio de la prisionera se caracteriza por la repetición compulsiva de una frase sobre la que conviene detenerse:

Me decía: "No te dejes ensuciar, que vos no sos uno de ellos”. Y me decía: “¿Vos sabés donde estamos, no? Vos venís de afuera. Vos sabés dónde estamos, ¿no? (...) Yo te doy el número de un abogado y vos avisás dónde estamos. Nada más. A vos no te va a pasar nada" [...] Ella, a través de la puerta me decía: "Vos no sos uno de ellos." (Kohan 136)

Ésta última oración está dirigida directamente a su interlocutor diegético -el conscripto-, pero al mismo tiempo, en su insistencia, va configurando un receptor extradiegético que pueda responder de una manera opuesta al conscripto. En otras palabras, como lectores sabemos que el narrador efectivamente "es uno de ellos", por lo cual la afirmación "voz no sos uno de ellos" se torna inverosímil y, nuevamente, es disparada hacia otro receptor que, aunque indefinido, posee una presencia transversal. Es así como se construye el 'filtro moral', combinando expresividad con referencialidad, potenciando en el receptor una profundización en la comprensión del 'daño moral' de las víctimas de represión, pero además pone atención sobre los modos en que la población circundante se escondió en el anonimato para hacer caso omiso de las injusticias que ocurrían a su alrededor. 


\section{Espejos quebrados de Ángel Saldomando: Interrogantes y pasados ineludibles}

La novela de Saldomando narra la historia de Gregorio Fuentes, un policía que debe enfrentar su pasado de vinculación a un grupo represivo, ya que su hija se entera de la verdad. Es así como se comienza a destapar la actualidad de este grupo llamado Los Pájaros y vamos conociendo cómo cada uno logró enriquecerse gracias a la apropiación y blanqueamiento de bienes de desaparecidos. La narración se concentra en el presente como un inevitable ajuste de cuentas, donde se entreteje una compleja red de sujetos y poderes, memorias y traumas que deben resolverse, pero que podrían haber seguido inmutables si es que nadie hubiese intervenido la rutina.

Cuando su hija decide declarar ante un organismo de Derechos Humanos, Gregorio se debate entre testificar y corroborar la historia de Aurora o mantener todo como estaba. Esta encrucijada es tanto familiar como moral. El personaje tiene que recuperar la filiación con su hija, para lo cual ella le pide un acto ético de alcance social: denunciar a los demás miembros del grupo Los Pájaros. En el proceso de decisión, la narración va insertando fragmentos del pasado de Gregorio, donde es caracterizado como un empleado pasivo ante las órdenes e inmutable al horror que envolvió sus prácticas. No se atrevió a desligarse de la policía: "Yo no tenía dónde ir, no sabía hacer otra cosa, pensé que las cosas pasarían. Estaba comenzando mi carrera no quería perderla, me había costado" (Saldomando 74). No obstante lo anterior, se nos entrega información acerca de su participación concreta, lo que nos permite conocer más a fondo su vinculación y, así, desmitificar la figura del verdugo. "Nunca aceptó dinero o entrar en el reparto. Hacía su trabajo taciturno, estaba encargado de recolectar la información, luego esperaba que pasaran las cosas" (95). Además de no aceptar el dinero, posteriormente nos enteramos de que consiguió pasar a Argentina a varios militantes perseguidos, a través de un amigo que vivía cerca de la frontera. De este modo, en Gregorio no observamos la sumisión completa; la novela, más bien, lo inserta en una zona media, a través de la que consigue sobrellevar el horror.

Muy a pesar de esta zona media, el personaje de Gregorio traza una línea de sentido directa con el conscripto de la novela de Kohan, en tanto ambos actúan como subordinados del poder represor, sin emitir 
cuestionamientos ni obstáculos. Es más, Saldomando insiste en el tema al insertar otro personaje de este tipo -Gorrión- y describirlo de la siguiente manera:

Su especialidad era ejecutar órdenes sin preguntar, había ejecutado mucho y preguntado muy poco. Sin ese talento, multiplicado por un número indeterminado de personas, ninguna organización podría funcionar. La idea de que las órdenes fueran contrastadas con un ideal ético para establecer un criterio de justeza le parecía fuera de la realidad, más aún en épocas turbulentas. (142)

Cuando Gregorio se decide a cooperar y declarar, opta por un testimonio escrito y, con ello, pone en práctica la memoria como ejercicio moral, tal como lo entiende Schmucler (2006): "La memoria es la práctica de una ética. Una ética que está antes del hacer, antes de la historia, pero que sólo se muestra en ese hacer" (Schmucler párrafo 3). En la redacción se aprecia cómo el ejercicio ético le resulta ajeno y distante:

Repasaba fechas, nombres, documentos, rememoraba imágenes pero no conseguía escribir nada. Estaba en blanco. Imaginó al inicio que era como escribir un informe y que eso sería fácil, había hecho muchos en su profesión. Era muy distinto explicar un giro tan brutal en la vida, las personas que habían tomado parte de ello adquirían peso propio y rompían el papel (139).

El filtro moral de esta novela se va construyendo también a partir de la efectividad comunicativa de las preguntas que hacen los personajes más jóvenes al enterarse de la verdad. Aurora y Víctor representan a las nuevas generaciones de hijos de la dictadura, hijos de verdugos y víctimas, respectivamente, a quienes se les desajusta el presente ante la develación del trauma de sus padres: “¿Cómo su padre había podido participar? ¿Colaborar hasta ese punto con un régimen que había secuestrado, torturado, asesinado? ¿Cómo había conservado su puesto?" (38). Tal como explica Lara (2009), por primera vez pueden ver el trauma histórico como si fuera la vida misma y no como un episodio lejano de la historia del país. Es cuando pueden evaluar su propia relación con el pasado, que en Aurora se traduce en vergüenza y sensación de ignorancia. "Aurora repasaba sus últimos años, su carrera universitaria, 
su vida cotidiana, las caras de amigos y amigas. Todo le parecía frívolo ahora. Se ruborizó inconsciente con una vergüenza retrospectiva" (133). De este modo, la novela despliega y escenifica el juicio moral colectivo de las generaciones recientes.

Finalmente, Espejos quebrados expone la importancia de la apertura pública de las memorias de represión con el gesto final de Gregorio de compartir su vivencia y transformarla en testimonio escrito, el cual además cumplirá una función punitiva al ser entregado a Marcela, la abogada de Derechos Humanos. Para Lara (2009), este tipo de actos "permiten la entrada de nuevas historias que amplían nuestras capacidades críticas y también nuestro margen de análisis crítico acerca de lo que aquellas representan" (23). Si bien la novela no imagina la repercusión pública del destape de un testimonio como éste, sí consigue proyectarlo a través de una serie de preguntas que adquieren resonancia extratextual, promoviendo así una mirada cívico-ética amplia: -“¿Eran todos igualmente responsables? ¿Alguno podía aparecer bajo una luz más benévola, menos culpable? ¿Lo era él igual que todos? ¿Podía él distribuir las culpas? ¿Qué cambiaba que se supiera esta parte de historia?" (139).

\section{Memorias del río inmóvil de Cristina Feijóo: Imaginando posibles retornos del trauma}

La novela de Cristina Feijóo (2001), Memorias del río inmóvil, nos presenta la historia de cómo rearman sus vidas Juan y Rita, una pareja de militantes de los noventa, luego de la prisión de siete años sufrida por él y el exilio vivido por ella. En la novela se advierte el tema del vacío comunicativo en el que quedó la generación de víctimas de la represión militar, quienes han debido olvidar sus experiencias dentro de un contexto neoliberal en el que ya no tienen cabida sus memorias, ni siquiera entre ellos mismos. Es así como este matrimonio ha decidido no comentar una palabra sobre su pasado y pretenden insertarse en la vida progresista de la nueva Argentina: "Nada había cambiado en esos siete años entre Juan y yo. Nada. Eso decidimos él y yo esa tarde. La tarde que asesinamos el pasado"11 (Feijóo 41).

11 Las cursivas son propias del texto original. 
Sin embargo, todo se quiebra con la reaparición de Floyt, un amigo de militancia desaparecido y que ahora reaparece en sus vidas como mendigo. Esta reaparición abre la posibilidad a los personajes de volver a preguntarse por el pasado y las respuestas serán distintas: mientras Rita instaura una rutina de visitas a este mendigo enajenado, Juan se niega a enfrentarse a esta posibilidad, por todo lo que ella puede implicar: “Él no es Floyt. Floyt está muerto [...] Estás queriendo retener un pasado que no tiene retorno y de eso no puede resultar nada bueno. Esto hay que cortarlo de raíz, antes de que te haga daño. No quiero que vuelvas a ver a ese hombre. No quiero que lo veas nunca más. ¿Está claro?" (119).

En las conversaciones que entabla la protagonista con Floyt, se observa la constante tensión dialógica entre el deseo de compartir la experiencia traumática y la imposición de una suerte de contrato tácito de silencio que obliga a no tocar el pasado. La necesidad de actualizar la memoria, junto a la imposibilidad de hacerlo, es una directriz de sentido que atraviesa toda la narración y que se ancla en la no-comunicación o intercambio de experiencias entre los personajes unidos por el trauma.

De este modo, si bien se fijan los pilares de la situación comunicativa en la ficcionalización de un imposible (que el detenido desaparecido vuelva a deambular por la ciudad y que sea encontrado por una de sus antiguas compañeras de militancia), no logra llevarse a cabo la interacción comunicativa propiamente dicha. Se subraya así la importancia de la dimensión ética, específicamente en lo que María Pía Lara ha denominado el 'daño moral', es decir, los efectos de las heridas contra la identidad de los seres humanos, las que se grafican en el habla mutilada de los personajes traumatizados de la novela de Feijóo.

Paralelamente a la historia de Rita y Juan, se nos muestra el espacio donde trabaja la protagonista: un trasfondo de profesionales superfluos, aparentemente desligados del horror de dictadura. Juan "critica abiertamente la frivolidad, el vacío y el individualismo de las compañeras de trabajo de Rita" (64); en cambio, para ella, son una especie de escape: "Las observa y se admira: son caraduras, procaces, ambiciosas; le gustaría entenderlas, ser como ellas. No enteramente, un poco. Ser un poco como ellas" (64). Si bien contemplamos en este ambiente ostentosas fiestas, casas lujosas y problemas triviales, poco a poco el narrador va focalizando la revelación de una verdad oculta. Es tanto Rita como Pinino, el hijo de su colega Julieta, quienes se encargan de armar las piezas de este puzle 
memorialístico: "Pinino intuye por dónde buscar. Desde el momento en que vio las fotos, sus tentáculos mentales se lanzaron hasta los últimos rincones de la memoria y extrajeron con precisión imágenes olvidadas, juntaron caras, momentos, lugares de modo que su pasado ya no es el mismo" (167).

Pinino es descrito como unjoven homosexual, promiscuo y materialista que se va enterando poco a poco que en realidad es un bebé apropiado y que su admirada supuesta madre le ha ocultado su desempeño como amante ocasional de militares. De este modo, su historia se transforma en un contrapunto en sordina que solo hacia el final consigue envergadura. Es una trama necesaria para entender la actualidad de la dimensión moral del trauma y de la importancia de la develación de las prácticas de aquella época.

La novela representa ampliamente no sólo a quienes fueron víctimas o victimarios, sino que también a aquellos que permitieron que este sistema existiese. De este modo, es la idea de una responsabilidad compartida por toda la sociedad argentina la que emerge en estas líneas y que hace eco de la propuesta de Pilar Calveiro (1998) cuando expresa: "el infierno del campo y la sociedad se pertenecen, por eso héroes y traidores, víctimas y victimarios son también esferas interconectadas entre sí y constitutivas del entramado social, en el que todos están incluidos. Todas las víctimas son inocentes y ninguna lo es, en sentido estricto" (137).

Nos dice Di Marco (2003) sobre las ficciones que hacen memoria: "Se escribe para ejercer la memoria, actuarla y actualizarla como una evocación, como una rememoración constante de la ausencia de verdad y de justicia; se escribe para llenar, poniendo en evidencia, los huecos de esa ausencia" (5). En este sentido, la novela de Feijóo representa dicha evocación mediante Floyt, el mendigo enajenado por el trauma, que funciona como una sinécdoque del olvido social que muestra la novela.

Floyt es un cachetazo en el alma. Él y yo somos los símbolos de que algo no está bien en este simulacro de país. En esta ciudad donde nos cruzamos en restaurantes, en reuniones de consorcio, en algún avión, en los semáforos: nos miramos de remise a remise, de coche a coche, el que torturaba y el torturado. Cada uno absorto en su negocio del día. (111) 
A través del personaje de Floyt podemos responder a las preguntas que formulara Vezzetti (1994) en relación al rol la memoria de los muertos/desaparecidos en la sociedad argentina: “ ¿Es la memoria de los muertos una función de la presencia, una repetición que viene a colmar la ausencia o es el registro de un sentido que sólo se construye sobre la angustia de un vacío definitivo? ¿Es la reaparición de lo vivido o la construcción de una historia?" (1).

Cristina Feijóo parece inclinarse por un punto medio: la construcción de una historia que no puede nunca contarse y que, por lo tanto, solo matiza la ausencia con otro color.

\section{Relaciones discursivas y espacios comunes}

En este apartado proponemos una breve panorámica comparativa, delimitando en las novelas nódulos de discusión repetitivos, para así trazar relaciones discursivas entre las mismas. En la atmosfera de ambigüedad moral que caracteriza todos estos mundos narrativos, observamos al menos dos puntos de conexión: primero, los personajes subalternos de la dictadura, y segundo, los vestigios individuales y colectivos del trauma hoy en día. En relación al primer tema, advertimos la acentuación sobre personajes que se ubican en los bordes de la colaboración, es decir, aquellos que sin ser los protagonistas, ayudan cumpliendo órdenes y anulando su propia capacidad ética. Esto se aprecia en las novelas de Kohan y Saldomando, en los personajes del conscripto y El Gorrión, respectivamente, pero también en Irene/Lorena de La vida doble, al situarse desde la ambigüedad para evaluar retrospectivamente su colaboración con la dictadura. A través del gesto de la traición y una corporalidad/identidad fracturadas, la protagonista consigue abrir el diálogo hacia la multitud de factores y tipos de sujetos involucrados en el trauma reciente.

El tema de la responsabilidad compartida en dictadura se ha ido perfilando como una instancia de reflexión sobre el rol de la ciudadanía, articulando una fuerte crítica acusatoria a todos aquellos que prefirieron no enterarse o no involucrarse con la tortura sistemática, la desaparición y los crímenes durante el régimen militar. Tomando esta crítica como base, estas narrativas construyen otra idea similar -y casi especular- contra aquellos que aún hoy en día prefieren hacer oídos sordos antes los numerosos testimonios que se han hecho públicos, de 
un buen tiempo a esta parte. En este sentido, los personajes secundarios individualizan la colectividad anónima, posicionándose fuera del clásico binomio víctima/ victimario ${ }^{12}$.

En relación a los vestigios del trauma, estas novelas evalúan las repercusiones actuales desde el cruce entre lo individual y lo colectivo, focalizando aquellas tensiones de la memoria que ya se han densificado en un discurso social concreto. Destacamos aquí los modos en que las novelas imaginan retornos del pasado a partir de situaciones ineludibles, y que van permitiendo que estos vestigios revelen secretos encubiertos. Es así como a partir de una entrevista (La vida doble), o de las interrogantes de los hijos (Espejos quebrados) o mediante el increíble regreso de un detenido desaparecido (Memorias del río inmóvil), las verdades van saliendo a flote, destacándose dos grandes temas: la apropiación ilegal de bebés y el enriquecimiento sucio.

De este modo, observamos cómo el bebé de la mujer torturada se ha convertido en el consentido sobrino del Doctor, en Dos veces junio, o descubrimos que Pinino es en realidad el hijo de Floyt, robado de su esposa en tortura. En segundo lugar, vemos al grupo Los Pájaros como una muestra del enriquecimiento organizado de militantes de derecha, y cómo estas prácticas se mantienen impunes mucho tiempo después: "el botín rondaba los ciento veinte millones de dólares. Cuando en el horizonte se dibujó la transición, el grupo anticipó la legalización del saqueo y negoció su retiro" (Saldomando 94). El mismo trasfondo se aprecia en la novela de Feijóo, sobre todo en el lujo y ostentación que envuelve a Julieta: "Le resulta curioso el insaciable deseo de ascenso social de Julieta, su gusto por lo caro, su correteo detrás del coche de moda, de la última marca de reloj" (Feijóo 146).

Con las dos temáticas se ponen de relieve los modos en que todavía siguen funcionando las redes de poder establecidas bajo represión -asunto propio de la memoria colectiva- asociándolo con las memorias individuales al imaginar distintas posibilidades filiales para afrontar la verdad revelada: el desprecio de la hija hacia la madre en La vida doble; el perdón hacia el padre en el caso de Aurora y Gregorio en Espejos

12 Un antecedente indiscutido de este tipo de personajes en la narrativa argentina es el médico Villa, de la novela del mismo nombre (Luis Gusmán, 1995), un médico asistente que se convierte en colaborador del régimen sin una convicción ideológica o política como motivo, sino que solo gracias a su condición sumisa y cobarde. Es así como mantiene a los torturados vivos para sacarles información, hasta que los verdugos deciden dejarlos morir. 
quebrados y, en la misma novela, el asesinato del padre (Hugo, jefe de Los Pájaros, es asesinado por su hijo Manuel al enterarse del pasado de su padre); y finalmente la aprobación de la madre manchada por la negación a la verdad en Memorias del río inmóvil:" ¿Pero alguien se pregunta si yo quiero salirme de acá? ¿Quiero yo que alguien me diga quién carajo soy? ¿Alguien me preguntó dónde quiero estar, si quiero estar aquí, o allí?" 13 (Feijóo 286-287).

\section{Conclusiones}

En este estudio hemos advertido una serie de conexiones entre cuatro ficciones narrativas que trabajan de un modo particular la recepción moral del trauma reciente. Luego del análisis, podemos dividir las conclusiones en dos grandes direcciones: por un lado, las relaciones interdiscursivas entre las novelas mismas; y por otro lado, el trabajo ético y estético sobre el oyente del testimonio.

En primer lugar, se advierten una serie de núcleos temáticos que dialogan entre sí: enriquecimiento ilegal, apropiación de bebés, relaciones filiales entre padres ehijos del trauma, impunidad, entre otros. En segundo lugar, constatamos que en las cuatro novelas se construye de distintas maneras un 'receptor ético', al que entenderemos doblemente como aquel oyente intradiegético que cumple el rol de escucha del testimonio $y$, a su vez, aquél receptor extradiegético al que se interpela en el texto y que es, en definitiva, el puente comunicativo que permitirá una reflexión ética en el entramado social que acoge la novela, específicamente en el debate público. Este 'receptor ético' debe ser capaz de emitir un juicio y reflexionar sobre su propia relación con el pasado reciente, esto es, su rol como individuo y ciudadano de una comunidad con un trauma histórico aún latente.

En cada ficción se generan preguntas que ameritan una posición moral, lo cual se logra mediante la construcción de una situación comunicativa que instala un escucha del testimonio, y que en el caso de Dos veces junio y Memorias del río inmóvil, la imposibilidad de retroalimentación entre los personajes produce un efecto de rebote proyectado hacia el lector. En las novelas chilenas, la estrategia comunicativa es relatar detalladamente las justificaciones de quienes colaboraron con la desaparición y tortura, lo 
que provoca una expansión en el campo de las culpas; no obstante, no inclina la toma de posición hacia un lado más que al otro. De este modo, se potencia la dimensión ilocucionaria en las estructuras narrativas y se renuevan los sentidos y definiciones atribuidas al testimonio y su relación dual con el testigo, configurando un nuevo triángulo que amplifica el problema de la elaboración del trauma hacia una nueva arista: el receptor.

Finalmente, este corpus apunta a repensar la recepción del testimonio como un ejercicio necesario de la memoria, con una importancia ética fundamental que vehiculiza las discusiones y tomas de posición en relación al futuro. Ya no es primacía la recuperación de las memorias del horror, pues proliferan los testimonios en distintos soportes textuales, lo urgente ahora es construir campos de escucha que supongan la incorporación de la experiencia del trauma desde la reflexión moral y social.

\section{Referencias Bibliográficas}

Aldaño, Fernanda. "Martín Kohan: Dos veces junio". Segunda poesía. Web. Junio 2004.

Angenot, Marc. Interdiscursividades. De hegemonías y disidencias. Córdoba: Ediciones Universidad Nacional de Córdoba, 1998.

"¿Qué puede la literatura? Sociocrítica literaria y crítica del discurso social." Estudios de Teoría Literaria-Revista digital: artes, letras y humanidades 4.7 (2015): 265-277.

Arpes, Marcela y Gasel, Alejandro. “La escritura literaria del trauma y las desconstrucciones de los mitos históricos en el territorio de la literatura argentina actual". Revista de Humanidades 24 (2011): 97-114.

Calveiro, Pilar. Poder y desaparición. Los campos de concentración en Argentina. Buenos Aires: Colihue, 1998.

Dalmaroni, Miguel. La palabra justa. Literatura, crítica y memoria en Argentina, 1960-2002. Mar del Plata: Melusina; Santiago de Chile: RIL. Web. 2004.

Di Marco, José. "Ficción y memoria en la narrativa argentina actual: La escritura como táctica". $V^{\circ}$ Congreso Internacional 
Orbis Tertius de Teoría y Crítica Literaria. Polémicas literarias, críticas y culturales. 13 al 16 de agosto de 2003, La Plata. Web.

Feijóo, Cristina. Memorias del río inmóvil. Buenos Aires: Aguilar, 2001.

Fontaine, Arturo. La vida doble. Buenos Aires: Tusquets Editores, 2010.

Garretón, Manuel Antonio. "Memoria y proyecto de país". Revista de Ciencia Política 2 (2003): 215-230.

Guzmán, Luis. Villa. Buenos Aires: Alfaguara, 1995.

Kaufman, Susana G. "Violencia y testimonio. Notas sobre subjetividad y los relatos posibles". Clepsidra. Revista Interdisciplinaria de Estudios sobre la memoria 1 (2014): 100-113. Web.

Kohan, Martín. Dos veces junio. Buenos Aires: De Bolsillo, 2010.

Lara, María Pía. Narrar el mal. Una teoría posmetafísica del juicio reflexionante. Barcelona: Gedisa, 2009.

Peris Blane, Jaume. "Contradicciones de la memoria. Ficcionalización del testimonio y figuración de la traición en La vida doble (Arturo Fontaine, 2010)". Les Ateliers du SAL 3 (2013): 49-63.

Pino-Ojeda, Waleska. Noche y Niebla: neoliberalismo, memoria y trauma en el Chile postautoritario. Santiago de Chile: Cuarto Propio, 2011.

Richard, Nelly. Residuos y metáforas: ensayos de crítica cultural sobre el Chile de la transición. Santiago de Chile: Cuarto Propio, 1998.

Robin, Régine, y Marc Angenot. "La inscripción del discurso social en el texto literario." Traducción: K. Urbánska, en M. Pierrete y C. Duchet, Sociocríticas, prácticas textuales: Cultura de fronteras. Amsterdam: Rodopi (1991): 51-79.

Saldomando, Ángel. Espejos quebrados. Santiago de Chile: Mago Editores, 2009.

Sarlo, Beatriz. Tiempo pasado. Cultura de la memoria y giro subjetivo. Una discusión. Buenos Aires: Siglo XXI, 2005. 
Schmucler, Héctor. "Las exigencias de la memoria". Punto de vista 68 (2000): 5-9.

. (2006). “La memoria como ética”. La Intemperie 34 (2006). Web. 23 Marzo 2015.

Souto, Luz C. "Los subalternos en las ficciones de apropiación de menores". Mitologías Hoy 8 (2013): 41-57.

Vezzetti, Hugo. "La memoria y los muertos". Punto de vista 49 (1994): 1-4. 